\title{
ANALISIS IDENTIFIKASI DAN PERANAN SEKTOR PERTANIAN DALAM PEMBANGUNAN WILAYAH DI KABUPATEN CILACAP
}

\author{
Ropingi ${ }^{1}$ \\ Agustono ${ }^{1}$ \\ Triasih Yuliani ${ }^{1}$ \\ ${ }^{1}$ Program Studi Sosial Ekonomi Pertanian/Agrobisnis Universitas Sebelas Maret \\ E-mail: rropingi@yahoo.co.id
}

\begin{abstract}
This study aimed to identify agriculture sector and sub-sector for region developing; to know of role of agriculture sector and sub-sector for region developing in Cilacap Regency. The used descriptive method, then the data analyze were Location Quotient (LQ) Approach, Income Multiplier effect, and Labour Multiplier effect. The research used secondary data, it was Gross Domestic Regional Product of Central Java and Gross Domestic Regional Product of Cilacap Regency based on 2000 constant price along the year of 1999 to 2003 and the labor of Cilacap Regency. The result of the research shows: the basic sectors of Cilacap Regency are manufacture industry, trading, hotel and restaurant sector. The contribution of agriculture sector in Cilacap Regency can be known from the Income Multiplier Effect along the year of analysis. In the labor side shows that the capacity of agriculture employment field more increase and so does the contribution of agriculture sector for the employment in Cilacap Regency.
\end{abstract}

Key word: cilacap regency, $L Q$, income and labor multiplier effect, basic sector

\section{PENDAHULUAN}

Perekonomian negara-negara yang sedang berkembang, seperti Indonesia, Malaysia, Thailand, dan Korea Selatan, yang semula dibanggakan akan dan sudah menjadi negara industri baru runtuh dilanda krisis moneter. Industri-industri yang telah dibangun dengan investasi besar, runtuh karena timbulnya krisis ekonomi di Indonesia, ratusan industri dari berbagai jenis terpaksa menghentikan produksinya, karena meningkatnya ongkos produksi yang disebabkan oleh menurunnya nilai mata uang rupiah terhadap mata uang dollar. Akibatnya jutaan buruh industri kehi- langan mata pencaharian mereka. Lain halnya dengan sektor pertanian, dalam keadaan krisis ekonomi yang berkepanjangan tetap eksis dan mampu bertahan di setiap aspeknya. Misalnya saja petani coklat yang meraup keuntungan berlipat karena harga coklat di pasaran internasional meningkat. Hal ini menyebabkan terjadinya perubahan pola pikir dari perencana pembangunan di negaranegara yang sedang berkembang termasuk Indonesia (Soetrisno, 2002).

Kabupaten Cilacap merupakan salah satu daerah di Indonesia yang mempunyai kawasan industri. Kawasan industri ini berlokasi 
di pusat ibukota kabupaten Cilacap. Industriindustri berskala besar maupun kecil memenuhi kawasan yang menjadi pusat industri, antara lain industri pengolahan minyak bumi dan gas milik negara, PT. Semen Nusantara dan PT. Semen Cibinong, pengolahan pasir besi, pemintalan kapas, pengolahan hasilhasil laut baik untuk konsumsi pasar lokal maupun untuk pasar internasional, dan masih banyak lagi.

Beragamnya industri di kabupaten Cilacap terlihat dari besarnya sumbangan sektor industri pengolahan terhadap PDRB kabupaten Cilacap. Berdasarkan data BPS kabupaten Cilacap, pada tahun 2000 sumbangan sektor industri pengolahan terhadap PDRB sebesar Rp.6,77714982 trilyun atau sekitar 49,10 persen dan meningkat pada tahun 2003 menjadi Rp.7.879.212,637 juta atau sekitar 50,11 persen. (BPS, 2001)

Bila dilihat kabupaten Cilacap secara keseluruhan, di bagian barat kabupaten Cilacap yang mempunyai karakteristik daerah relatif tinggi mencapai 700 meter di atas permukaan laut dan bergunung-gunung, terdapat beberapa perkebunan seperti perkebunan jati, karet, dan pinus yang cukup luas yaitu sekitar 10.084,328ha milik rakyat dan 44.877,412ha milik pemerintah. Bagian timur, yang merupakan daerah pesisir pantai banyak penduduknya yang memanfaatkan hasil laut sebagai sumber pendapatan keluarganya. Berdasarkan data BPS kabupaten Cilacap pada tahun 2003, penduduk kabupaten Cilacap bermatapencaharian sebagai petani sebesar 59,87 persen. Namun, sumbangan sektor pertanian pada PDRB relatif kecil bila dibandingkan dengan sektor industri pengolahan yaitu hanya sekitar 10 persen saja.

Melihat fenomena tersebut dan keterkaitannya dengan ketangguhan sektor pertanian dalam perekonomian, peneliti tertarik untuk mengidentifikasi sektor pertanian dan peranan sektor pertanian dalam pembangunan di wilayah kabupaten Cilacap yang dikenal sebagai kawasan industri. Dari latar belakang di atas dapat dirumuskan permasalahan sebagai berikut: (1) Apakah sektor pertanian merupakan sektor basis dalam pembangunan wilayah di kabupaten Cilacap?, (2) Seberapa besarkah peranan sektor pertanian dalam pembangunan wilayah di kabupaten Cilacap dilihat dari angka pengganda tenaga kerja dan angka pengganda pendapatan?

Berdasarkan perumusan masalah yang telah diuraikan di atas, maka tujuan penelitian yang ingin dicapai adalah (1) Untuk mengidentifikasi sektor pertanian dalam pembangunan wilayah di kabupaten Cilacap, (2) Untuk mengetahui peranan sektor pertanian dalam pembangunan wilayah di kabupaten Cilacap dilihat dari angka pengganda tenaga kerja dan angka pengganda pendapatan.

\section{METODE PENELITIAN}

Metode yang digunakan dalam penelitian ini adalah metode deskriptif. Menurut Surakhmad (1994), metode deskriptif yaitu memusatkan diri pada permasalahan-permasalahan yang ada pada masa sekarang, mengumpulkan data, disusun untuk dijelaskan dan kemudian dianalisis. Penentuan lokasi penelitian dilakukan secara sengaja (purposive), yaitu cara pengambilan lokasi penelitian dengan mempertimbangkan alasan dan sifat sampel yang diketahui (Singarimbun, 1995). Penelitian ini dilakukan di kabupaten Cilacap dengan pertimbangan: Sektor pertanian memberikan sumbangan yang besar terhadap pembentukan PDRB kabupaten Cilacap (tanpa minyak). 
Kegagalan panen pada dua sub sektor tersebut menyebabkan berkurangnya penyerapan tenaga kerja pertanian di kabupaten Cilacap. Pada tahun 2003 kontribusi sektor pertanian mengalami peningkatan dalam menciptakan kesempatan kerja sebesar 42.611,39. Hal ini menunjukkan daya tampung lapangan kerja sektor pertanian semakin bertambah sehingga kontribusi sektor pertanian dalam penyerapan tenaga kerja di kabupaten Cilacap mengalami peningkatan.

Kondisi sektor pertanian yang demikian memerlukan penanganan yang lebih serius dari pemerintah kabupaten Cilacap. Potensi sumber daya pertanian yang banyak tersedia harus lebih optimal dalam pemanfaatannya. Dalam Repetada kabupaten Cilacap Tahun 2003 sektor pertanian menjadi prioritas dalam pembangunan daerah di kabupaten Cilacap. Rencana pembangunan sektor pertanian antara lain: peningkatan ketahanan pangan, pengembangan sistem agrobisnis, investasi sumber daya perikanan laut, pengembangan Segara Anakan dan Nusakambangan, pengembangan dan peningkatan usaha kehutanan dan perkebunan.

\section{KESIMPULAN}

(1) Selama tahun analisis yaitu tahun 19992003 sektor pertanian di kabupaten Cilacap tidak menjadi sektor basis dalam pembangunan wilayahnya, (2) Sub sektor pertanian yang menjadi basis yaitu sub sektor kehutanan, sedangkan sub sektor tanaman bahan pangan, sub sektor peternakan, sub sektor perkebunan dan sub sektor perikanan merupakan sektor non basis dalam pembangunan wilayah di kabupaten Cilacap, (3) Selama tahun 1999-2003 peranan sektor pertanian di kabupaten Cilacap dilihat dari angka pengganda pendapatan memiliki kecenderungan meningkat. Sub sektor tanaman bahan pangan peranannya juga mengalami kecenderungan meningkat dari tahun ke tahun, sedangkan sub sektor perkebunan dan sub sektor kehutanan peranannya dalam sektor pertanian mengalami fluktuatif, dan sub sektor perikanan peranannya mengalami kencenderungan menurun. Bila dilihat dari angka pengganda tenaga kerja, peranan sektor pertanian dalam penyerapan tenaga kerja di kabupaten Cilacap selama tahun 1999-2003 sangat berfluktuatif.

Dari hasil analisis diperoleh bahwa sektor industri pengolahan dan sektor perdagangan, hotel dan restoran merupakan sektor basis di kabupaten Cilacap, namun sektor keuangan, sewa dan jasa perusahaan tidak basis. Lazimnya, apabila dalam suatu wilayah sektor industri pengolahan dan sektor perdagangan, hotel dan restoran merupakan sektor basis maka sektor keuangan, sewa dan jasa perusahaan juga basis. Bagi yang berminat untuk melakukan penelitian dengan topik pembangunan wilayah hal ini dapat dikaji lebih lanjut faktor apa yang menyebabkan hal ini terjadi dan keterkaitan antarsektor dalam pembangunan wilayah di kabupaten Cilacap sebagai bahan penelitiannya.

\section{DAFTAR PUSTAKA}

Arsyad. L. 1999. Ekonomi Pembangunan. Edisi Ke-empat. Yogyakarta: Penerbit STIE YKPN.

BAPPEDA. 2004. Repetada Kabupaten Cilacap Tahun 2005. Cilacap: BAPPEDA.

BPS. 2001. Produk Domestik Regional Bruto Kabupaten Cilacap Tahun 2000. Kabupaten Cilacap: Badan Pusat Statistik.

BPS. 2000-2004. Produk Domestik Regional Bruto Kabupaten Cilacap. Tahun 1999- 
2003. Kabupaten Cilacap: Badan Pusat Statistik.

BPS. 2003. Kabupaten Cilacap dalam Angka Tahun 2003. Kabupaten Cilacap: Badan Pusat Statistik.

Budiharsono, S. 2001. Teknik Analisis Pembangunan Wilayah Pesisir dan Lautan. Jakarta: Pradnya Paramita.

Singarimbun, M. 1995. Metode Penelitian Survei. Jakarta: LP3ES.

Soetrisno, Lukman. 2002. Paradigma Baru Pembangunan Pertanian. Yogyakarta: Kanisius.
Sukirno, Sadono. 1994. Pengantar Teori Makroekonomi Edisi Kedua. Jakarta: PT. Raja Grafindo Perkasa.

Surakhmad, W. 1994. Pengantar Penelitian Ilmiah, Dasar Metode Teknik. Bandung: Tarsito.

Wuryandari, Puri. 2002. Analisis Potensi Ekonomi Sektoral Provinsi Jawa Tengah Tahun 1993-2001. Skripsi Mahasiswa S1 Fakultas Ekonomi UNS (tidak dipublikasikan). 


\title{
PEDOMAN PENULISAN \\ JURNAL EKONOMI PEMBANGUNAN FAKULTAS EKONOMI UNIVERSITAS MUHAMMADIYAH SURAKARTA
}

Terbit: 2 kali dalam setahun pada bulan Juni dan Desember

\author{
Akreditasi Jurnal: \\ KEPUTUSAN DIREKTUR JENDERAL PENDIDIKAN TINGGI \\ KEMENTERIAN PENDIDIKAN NASIONAL NOMOR: 51/DIKTI/Kep./2010 \\ (masa berlaku Juni 2010 s.d Juni 2013)
}

1. Artikel ditulis dengan bahasa Indonesia atau bahasa Inggris dalam bidang kajian masalah ekonomi dan pembangunan.

2. Substansi artikel diharapkan sejalan dengan Panduan Akreditasi Berkala Ilmiah 2006, yang diterbitkan Direktorat Penelitian dan Pengabdian kepada Masyarakat (DP2M) Direktorat Jenderal Pendidikan Tinggi Republik Indonesia).

3. Artikel ditulis dengan kaidah tata bahasa Inggris ataupun bahasa Indonesia yang baik dan benar.

4. Sistematika Penulisan

Sistematika penjenjangan atau peringkat judul artikel dan bagian-bagiannya dilakukan dengan cara berikut:

(1) Judul ditulis dengan huruf besar semua, di bagian tengah atas pada halaman pertama

(2) Sub Bab Peringkat 1 ditulis dengan huruf pertama besar semua di tengah/center

(3) Sub Bab Peringkat 2 ditulis dengan huruf besar-kecil rata tepi kiri

- Sistematika artikel hasil penelitian adalah: judul; nama penulis (tanpa gelar akademik); nama dan alamat institusi, alamat e-mail penulis, abstrak (maksimum 150 kata) yang berisi tujuan, metode, dan hasil penelitian; kata kunci (4-5 kata kunci); pendahuluan (tanpa ada subjudul) yang berisi latar belakang, sedikit tinjauan pustaka, dan tujuan penelitian; metode; hasil penelitian dan pembahasan; kesimpulan; daftar rujukan (hanya memuat sumber-sumber yang dirujuk).

\section{JUDUL UTAMA:}

\section{Sub Judul}

Penulis $1^{1}$ dan Penulis $2^{2}$

${ }^{1}$ Nama instansi/lembaga Penulis 1

Alamat lengkap instansi penulis, nomor telepon instansi penulis

${ }^{2}$ Nama instansi/lembaga Penulis 2

Alamat lengkap instansi penulis, nomor telepon instansi penulis

(jika nama instansi penulis 1 dan 2 sama, cukup ditulis satu saja)

E-mail penulis 1 dan 2:

Abstrak: Abstrak dalam bahasa Indonesia (125 - 150 kata)

Kata kunci: 4 - 5 katal frase

Abstract: Abstract in english (125 - 150 words)

Keywords: $4-5$ words/ phrase

\section{PENDAHULUAN}

(berisi latar belakang, sekilas tinjauan pustaka, dan tujuan penelitian, yang dimasukkan dalam paragraf paragraf bukan dalam bentuk subbab)

METODE PENELITIAN

Subbab

Subbab

...

\section{HASIL ANALISIS DAN PEMBAHASAN}

Pedoman Penulisan Jurnal Ekonomi Pembangunan FE Universitas Muhammadiyah Surakarta 


\title{
Subbab
}

\section{KESIMPULAN \\ DAFTAR PUSTAKA}

- Sistematika artikel hasil pemikiran adalah: judul; nama penulis (tanpa gelar akademik); nama dan alamat institusi, alamat e-mail penulis, abstrak (maksimum 150 kata); kata-kata kunci (4-5 kata kunci); pendahuluan (tanpa ada subjudul) yang berisi latar belakang dan tujuan atau ruang lingkup tulisan; bahasan utama (dapat dibagi ke dalam beberapa sub-judul); penutup atau kesimpulan; daftar rujukan (hanya memuat sumber-sumber yang dirujuk).

\section{JUDUL UTAMA: \\ Sub Judul}

Penulis $1^{1}$ dan Penulis $2^{2}$

${ }^{1}$ Nama instansi/lembaga Penulis 1

Alamat lengkap instansi penulis, nomor telepon instansi penulis

${ }^{2}$ Nama instansi/lembaga Penulis 2

Alamat lengkap instansi penulis, nomor telepon instansi penulis

(jika nama instansi penulis 1 dan 2 sama, cukup ditulis satu saja)

E-mail penulis 1 dan 2 :

\author{
Abstrak: Abstrak dalam bahasa Indonesia (125--150 kata) \\ Kata kunci: 4 - 5 katal frase \\ Abstract: Abstract in english (125 - 150 words) \\ Keywords: $4-5$ words/ phrase

\section{PENDAHULUAN PEMBAHASAN \\ KESIMPULAN} \\ DAFTAR PUSTAKA
}

5. Artikel diketik pada kertas kwarto berkualitas baik. Dibuat sesingkat mungkin sesuai dengan subyek dan metode penelitian (bila naskah tersebut ringkasan penelitian), biasanya 20-25 halaman dengan spasi satu, untuk kutipan paragraf langsung diindent (tidak termasuk daftar pustaka).

6. Marjin atas, bawah, dan samping harus dibuat paling tidak satu inci.

7. Abstrak, ditulis satu paragraf sebelum isi naskah. Abstrak dalam dua bahasa yaitu bahasa Indonesia dan bahasa Inggris. Abstrak tidak memuat uraian matematis, dan mencakup esensi utuh penelitian, metode dan pentingnya temuan dan saran atau kontribusi penelitian.

8. $\quad$ a. Penulisan numbering diintegrasikan dalam paragraf, contohnya:

Tujuan dilakukannya penelitian ini adalah: (1) Untuk mengetahui apakah CSR berpengaruh positif terhadap nilai perusahaan, (2) Untuk mengetahui apakah persentase kepemilikan manajemen berperan sebagai variabel moderating dalam hubungan antara CSR dengan nilai perusahaan, dan (3) Untuk mengetahui apakah tipe industri berperan sebagai variabel moderating dalam hubungan antara CSR dengan nilai perusahaan?

b. Penulisan bullet juga diintegrasikan dalam paragraf dengan menggunakan tanda koma pada antarkata/kalimat tanpa bullet.

9. Tabel dan gambar, untuk tabel dan gambar (grafik) sebagai lampiran dicantumkan pada halaman sesudah teks. Sedangkan tabel atau gambar baik di dalam naskah maupun bukan harus diberi nomor urut.

- Tabel atau gambar harus disertai judul. Judul tabel diletakkan di atas tabel sedangkan judul gambar diletakkan di bawah gambar.

Pedoman Penulisan Jurnal Ekonomi Pembangunan FE Universitas Muhammadiyah Surakarta 
- Sumber acuan tabel atau gambar dicantumkan di bawah tabel atau gambar.

- Garis tabel yang dimunculkan hanya pada bagian header dan garis bagian paling bawah tabel sedangkan untuk garis-garis vertikal pemisah kolom tidak dimunculkan.

Contoh: Tabel

Tabel 1. Bentuk-bentuk Mobilitas Penduduk

\begin{tabular}{llll}
\hline No & Bentuk Mobilitas & Batas Wilayah & Batas Waktu \\
\hline 1. & Ulang-alik (commuting) & Dukuh (dusun) & 6 jam atau lebih dan kembali pada hari yang sama \\
2. & Menginap/mondok di daerah tujuan & Dukuh (dusun) & Lebih dari satu hari tetapi kurang dari 6 bulan \\
3. & Permanen/menetap di daerah tujuan & Dukuh (dusun) & 6 bulan atau lebih menetap di daerah tujuan \\
\hline
\end{tabular}

Sumber: Ida Bagoes, 2000

\section{Contoh: Gambar}

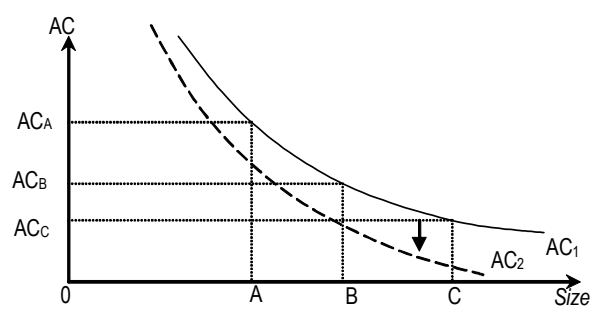

Sumber: Saunders (1997: 291)

Gambar 2. Dampak Peningkatan Teknologi

10. Cara penulisan rumus, Persamaan-persamaan yang digunakan disusun pada baris terpisah dan diberi nomor secara berurutan dalam parentheses (justify) dan diletakkan pada margin kanan sejajar dengan baris tersebut. Contoh:

$\mathrm{wt}=\mathrm{f}\left(\mathrm{y}_{\mathrm{t}}, \mathrm{k}_{\mathrm{t}}, \mathrm{w}_{\mathrm{t}-1}\right)$

11. Keterangan Rumus ditulis dalam satu paragraf tanpa menggunakan simbol sama dengan (=), masingmasing keterangan notasi rumus dipisahkan dengan koma. Contoh:

Dimana $\mathbf{w}$ adalah upah nominal, $\mathbf{y t}$ adalah produktivitas pekerja, kt adalah intensitas modal, $\mathbf{w}_{\mathbf{t}-\mathbf{1}}$ adalah tingkat upah periode sebelumnya.

12. Perujukan sumber acuan di dalam teks dengan menggunakan nama akhir dan tahun. Kemudian bila merujuk pada halaman tertentu, penyebutan halaman setelah penyebutan tahun dengan dipisah titik dua. Untuk karya terjemahan dilakukan dengan cara menyebutkan nama pengarang aslinya.

Contoh:

- Yuni (2008: 23) memandang bahwa .....

- Fatimah dan Daryono (1997) menunjukkan adanya ....

- Didit dkk (2007) berkesimpulan bahwa....

- Untuk meningkatkan perekonomi daerah .... (Yuni, Triyono, dan Agung Riyardi, 2009).

- Maya (2009) berpendapat bahwa ....

13. Setiap kutipan, baik langsung maupun tidak langsung, harus diikuti sumbernya (lihat poin no. 10) dan dicantumkan juga dalam daftar pustaka. Contoh:

Di dalam paragraf isi tercantum kutipan dari: Buiter (2007:15) berpendapat bahwa...

Maka dalam daftar pustaka harus ada sumber referensinya seperti berikut:

Buiter, W. H., (2002). The Fiscal Theory of the Price Level: A Critique, Economic Journal, 112(127): 459-480.

Pedoman Penulisan Jurnal Ekonomi Pembangunan FE Universitas Muhammadiyah Surakarta 
14. Sedapat mungkin pustaka-pustaka yang dijadikan rujukan adalah pustaka yang diterbitkan 10 tahun terakhir dan diutamakan dari jurnal ilmiah.

15. Unsur yang ditulis dalam daftar pustaka secara berturut-turut meliputi: (1) nama akhir pengarang, nama awal, nama tengah, tanpa gelar akademik, (2) tahun penerbitan, (3) judul termasuk subjudul, (4) tempat penerbitan, (5) nama penerbit.

Contoh cara penulisan:

a. Format rujukan dari buku: Nama pengarang, (tahun), Judul Buku, edisi, Kota penerbit, Nama penerbit. Jika penulis sebagai editor tunggal, ditulis (Ed.) di belakang namanya. Ditulis (Eds.) jika editornya lebih dari satu orang. Kemudian bila pengarang lebih dari tiga orang, dituliskan nama pengarang pertama dan yang lain disingkat 'dkk' (pengarang domestik) atau 'et.al.' (pengarang asing).

Enders, W., (2004), Applied Econometric Time Series, Second edition, New York: John Wiley \& Sony Inc. Purnomo, Didit (Ed.). (2005). The Role of Macroeconomic Factors in Growth. Surakarta: Penerbit Muhamadiyah University Press.

b. Format rujukan dari artikel dalam buku ditulis: Nama editor (Ed.), (tahun), Judul tulisan/karangan. Judul buku, hlm atau pp., kota penerbit: nama penerbit

Daryono (Ed.). (2005). Concept of Fiscal Decentralization and Worldwide Overview (hlm. 12-25). Surakarta: Penerbit Muhammadiyah University Press.

c. Format rujukan dari artikel dalam jurnal/majalah/koran: Nama pengarang (tahun). judul tulisan/ karangan. Nama jurnal/majalah/koran, hlm atau pp., volume (nomor), halaman. Jika rujukan koran tanpa penulis, nama koran ditulis diawal.

Rodden, J., (2002). The dilemma of Fiscal Federalism: Grants and Fiscal Performance arround the World. American Journal of Political Science, 46 (3): 670-687.

Triyono (2008). Perimbangan Keuangan Pusat dan Daerah Sebagai Pelaksanaan Desentralisasi Fiskal Efek. Warta Ekonomi, Vol. 4, Agustus: 46-48.

Haryanto, S., (2007, 13 November). Desentralisasi Fiskal dan Pembangunan Ekonomi. Harian Jakarta, hlm.4.

Harian Jogjakarta, (2007, 1 April). Hubungan Keuangan Pusat-Daerah di Indonesia. hlm. 4.

d. Format rujukan dari internet, tanggal akses dicantumkan.

Setyowati, E.,. Keuangan Publik dan Sistem Harga. http://www.ekonomipublik.com/akt/pdf/akt452.pdf.

Diakses tanggal 27 Mei 2009.

\section{Pengiriman Artikel}

1. Artikel dikirimkan sebanyak 2 eksemplar hardcopy, dan softcopy berupa file. File bisa dikirim melalui email jepums@yahoo.co.id atau dalam media cd.

2. Artikel yang dikirim wajib dilampiri biodata ringkas pendidikan termasuk catatan riwayat karya-karya ilmiah sebelumnya yang pernah dipublikasikan, insitusi dan alamatnya, nomor telpon kontak atau e-mail penulis.

3. Penulis yang menyerahkan artikelnya kepada editor atau penerbit, harus menjamin bahwa naskah yang diajukan tidak melanggar hak cipta, belum dipublikasikan atau telah diterima untuk dipublikasi oleh jurnal lainnya.

4. Kepastian pemuatan atau penolakan naskah akan diberitahukan secara tertulis. Penulis yang artikelnya dimuat mendapatkan jurnal tersebut. Artikel yang tidak dimuat tidak akan dikembalikan.

\section{Alamat Redaksi Jurnal Ekonomi Pembangunan Fakultas Ekonomi Universitas Muhammadiyah Surakarta: \\ Redaksi Jurnal Ekonomi Pembangunan Fakultas Ekonomi Universitas Muhammadiyah Surakarta Jalan A. Yani Tromol Pos I Pabelan SURAKARTA 57102 Telp. 0271-717417 psw 229}

Pedoman Penulisan Jurnal Ekonomi Pembangunan FE Universitas Muhammadiyah Surakarta 
TENTANG JURNAL:

\title{
JURNAL EKONOMI PEMBANGUNAN
}

Kajian Masalah Ekonomi dan Pembangunan

ISSN 1411- 6081

\author{
Pimpinan Redaksi \\ Didit Purnomo
}

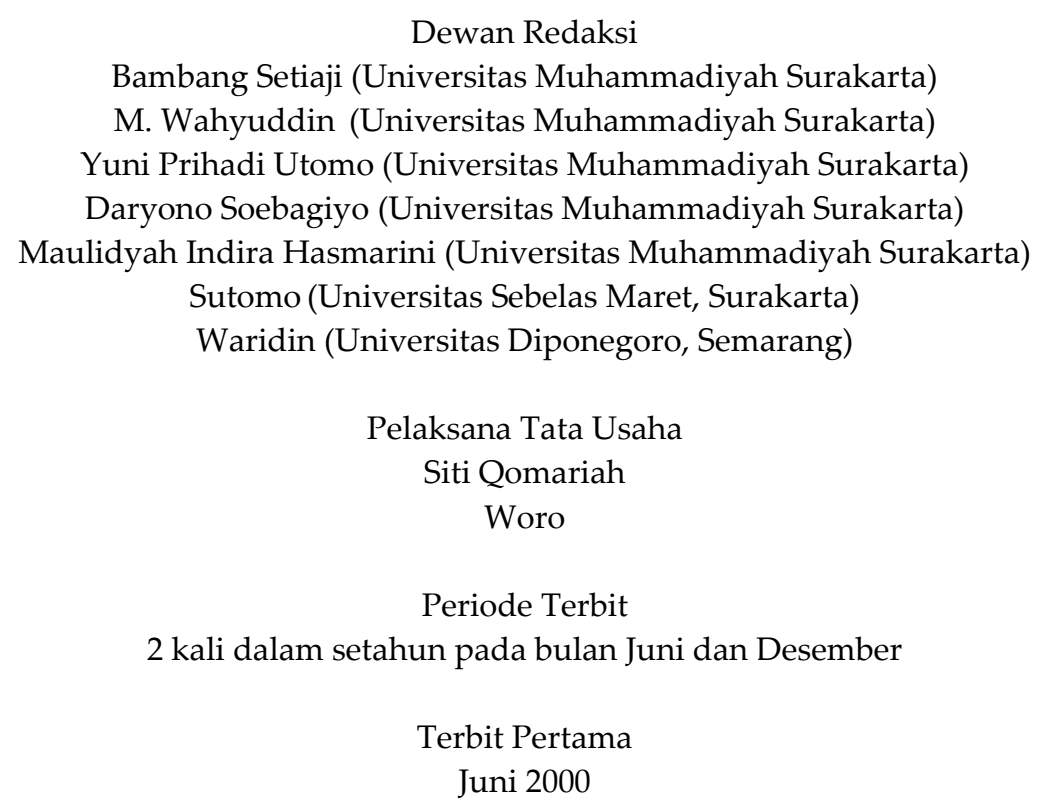

Jurnal EKONOMI PEMBANGUNAN merupakan jurnal ilmiah yang berisikan hasil penelitian dan kajian teoritis mengenai masalah-masalah ekonomi dan pembangunan, khususnya di Indonesia. Diterbitkan oleh Balai Penelitian dan Pengembangan Ekonomi Fakultas Ekonomi Universitas Muhammadiyah Surakarta.

Redaksi menerima sumbangan tulisan yang belum pernah diterbitkan atau dalam proses terbit oleh media lain. Naskah diketik di atas kertas HVS kuarto spasi satu sepanjang lebih kurang 20-25 halaman, dengan format seperti tercantum pada prasyarat naskah jurnal EKONOMI PEMBANGUNAN di halaman belakang. Naskah yang masuk akan dievaluasi dan disunting untuk keseragaman format dan tata cara lainnya.

Alamat Penyunting dan Tata Usaha: Subag Tata Usaha Fakultas Ekonomi Universitas Muhammadiyah Surakarta, Jl. A. Yani, Tromol Pos 1, Pabelan, Surakarta 57102; Telpon (0271) 717417 psw 229,

E-mail: jepums@yahoo.co.id

Website: http://www.ums.ac.id atau http://www.paradejurnal.wordpress.com

Simak informasi jurnal: http://www.paradejurnal.wordpress.com

Admin: Mirat Sidharta. SE

Pedoman Penulisan Jurnal Ekonomi Pembangunan FE Universitas Muhammadiyah Surakarta 